\title{
Factors of Knowledge Termination
}

\author{
Asira E. Asira, Phd. \\ Department Of Philosophy, University Of Calabar, Nigeria
}

\begin{abstract}
Knowledge is part of human nature. Much of man's search or quest is to know or have knowledge on one thing or the other.

Wisdom (knowledge) is the principal thing (Proverbs 4:7). Man is by nature apt to know and to have knowledge of the abstruse things and situations in the universe that he finds himself. But there are some issues, characteristics, instances and situations that militate the free-flow of knowledge acquisition. In effect, when one begins to abhor knowledge and embrace ignorance it is abnormal. When one begins to select what he should know at the expense of other knowledge, then he is losing some sort of knowledge. Knowledge is the pursuit and possession of clarity, certainty and truth for the solution of human problems. Hence, lack of the zeal to know and/or lack of knowledge and knowledge by selection make one less knowledgeable, less informed, less successful and less human - 'my people perish for lack of knowledge (wisdom)'. In this paper, attempts are made to outline the factors that hamper and terminate knowledge in human beings as teachers and/or learners.
\end{abstract}

Key Words: Knowledge, Termination, Factors.

\section{Introduction}

The quest for knowledge has been a longstanding burden of man and on man. But to date, 'no man has monopoly of knowledge'. However, knowledge is supposed to be pursued and acquired by all human beings. Philosophers like the skeptics, have argued against the possibility of knowledge acquisition (Ozumba, 70).

In the modern period, the rationalists and the empiricists were no longer arguing about the impossibility of knowledge acquisition but the sources of knowledge acquisition. While the empiricists hold that knowledge can be acquired through sense perception or sense-experience, the rationalists hold that knowledge can be acquired through reason (Dupre 20-21). However, Immanuel Kant was of the view that some knowledge can be acquired through both reason and/or experience (Millar, 264-265). Be that it were, man is still not nearer to acquiring certain and complete knowledge. In knowledge acquisition, one requires himself, the other human beings and the external world (the universe). In effect, human relations play a vital role in knowledge acquisition.

\section{Clarification Of Terms}

Knowledge can be defined as justified true belief. Knowledge is an embodiment of opinion, belief which has been scrutinized and confirmed to be true (Paul Edwards, 343). Another word of note here is 'truth' which is the same thing as real or certain. Knowledge is constituted if information that is true is passed unto somebody who in turn is knowledgeable about it and can make use of such knowledge and can also impart same to others. Knowledge can also have an element of belief. For instance, I have not travelled to America but my awareness of the existence of America is a mixture of knowledge and belief. This knowledge is belief-based. The day I travelled to America, then I will have full knowledge devoid of belief of America.

Termination is a noun referring to the act of ending something. That is, the end of something due to failure to comply with some conditions or factors. The verb of termination is terminate which would mean to end or to make something end (Hornby, 1235).

Factors are things that cause or influence something to happen or fail to happen, to succeed or fail (Hornby, 415). This can be the conditions that must be present or absent for something to happen or fail to happen.

\section{Some Human Characteristics For Knowledge Acquisition}

Some of the human relations characteristics for those who desire to learn and to leach include: Readiness to learn and teach, speaking to people, smile at people, being friendly and helpful to people, know and call people by name, be cordial, have a genuine interest in people, be thoughtful after people's opinions, be generous with praise, be considerate of the feelings of others, have fellow feeling, be ready to give quality service, be humane and humble be respectful, love peace and abhor violence, do not take things for granted, do not take nor use conceptions and statements as true without scrutiny and examination, and do not work with presupposition, 
Analysis of the above characteristics shows that if a man possesses them, he can learn and teach. In other words, they help to increase one's knowledge and he in turn increases others' knowledge. Human relations are important in all aspects of man's life (Maxwell 4). According to John Craig in Maxwell, no matter how much work you do, no matter how engaging your personality may be you will not enhance far in business if you cannot work through others' (Maxwell, 7). In fact, it is well acclaimed that $\mathrm{R}+\mathrm{R}-\mathrm{R}=\mathrm{R}+\mathrm{R}$ which can be interpreted thus:

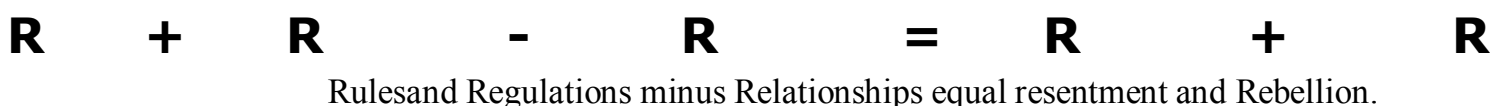

In poor relationship one can neither learn nor teach successfully. In attempt to suggest what really comes against human knowledge acquisition, Francis Bacon identified distempers of learning, namely, fantastical, which has to do with people who concern themselves with words, emphasizing text, languages and style. It is the truth afterwards that matters; contentious learning, this begins with fixed positions or points of view taken by earlier thinkers and those views are used as a starting point in contentious argumentations; and Delicate learning, which has to do with earlier authors who claim more knowledge than can be proved are accepted by readers as knowing as much as they claim (Aristotle, 208).

He also identified four idols namely, idols of the tribe, idols of the den (Cave), idols of the marketplace and idols of the theatre. Francis Bacon was in a running battle against the false approaches of metaphysics, and against superstition as he says, 'the search into final causes, is barren and produces nothing' (Blackburn, 34). This cannot be totally true in issues of knowledge acquisition because this approach is not holistic. Idols as Bacon used them are 'Eidola', 'the transient, and erroneous images of things' (Blackburn, 34).

Simple explanation of the idols and how they blur knowledge acquisition is as follows:

Idols of the tribe (idolatribus) are general tendencies to be deceived, inherent in human beings by nature. They include uncritical reliance on sense perception or sense experience, and tendencies to over generalize or jump to conclusions and ignore countervailing evidence against various views. Idols of the den or cave (idolaspecus) are distortions arising from our peculiar perspectives. This is in line with Plato's myth of the cave. This could be explained that whatever our minds 'seizes and dwells upon with peculiar satisfaction is to be held in suspicion' (Blackburn, 186). Idols of the market-place (idolafori) are errors that come in the course of communication with other human beings, hence, misunderstandings arise through abuses of words (Robert Audi, 60). Idols of the Theatre (idolaTheatri) are errors introduced by received theories. That is, they are errors that depend or occur as a result of the influence of received theories and the introduction of theological notions. As a matter of fact, these factors distort knowledge acquisition free-flow but they cannot be the only ones. Hence, call for numerous knowledge termination factors.

Knowledge acquisition for man is a continuum. This is why man comes to new knowledge, new understanding, new wisdom, etc. New people and new situations give us new knowledge. It is on the basis of new knowledge that old mistakes are realized and future mistakes avoided. Some of the main knowledge termination factors are: Human nature of concealment, claim of expertise, professionalism, fame, influence, extremism, power, authority, absence of the fear of God, pride, ignorance or lack of knowledge, evil or wickedness, blind love, tradition/superstition, suspicion (Lack of trust), poor leadership, poor followership, fear of failure, or fear of the unknown, sycophancy, fanaticism etc.

\section{Conclusion}

The list is inexhaustible but these are the main factors that terminate knowledge acquisition in all human beings. Imagine that these factors were representing sickness in a human body with their attending effects and impact, that body will never survive nor experience a movement of peace. This is how some of these or all these factors throw human beings bereft of knowledge and the end of such a man and of course, majority of human beings in the twenty-first $\left(21^{\text {st }}\right)$ century are full of regrets, crisis and violence. The absence of these factors can restore the much needed security and peace.

For Francis Bacon, 'once the idols are eliminated, the mind is free to seek and acquire knowledge' (Audi, 60). The same will happen when the afore-listed factors are eliminated. It is therefore, important knowledge termination factors in order to obtain true certain knowledge - you shall know the truth and the truth shall set you free (John 8;32 $\quad$ ). That is when man shall come to the realization of the fact that the present of ignorance and the absent of knowledge is responsible for the chaotic and riotous society. This realization will in turn breed social order. 


\section{Works Cited}

[1]. Audi, Robert. The Cambridge Dictionary of philosophy Edwinburgh: Cambridge University press, 1999.

[2]. Aristotle in stumpf S. E. Socrates to Sartre. London: McGraw-Hall 1999.

[3]. Blackburn, Simon. Oxford Dictionary of Philosophy, New York: Oxford University press, 1996.

[4]. Edwards, Paul. The Encyclopedia of Philosophy vol. 3 and 4, New York: Macmillan, 1967.

[5]. Hornby, A. S. Oxford Advance Learner's Dictionary of current English, New York: Oxford University press, 2001.

[6]. Maxwell, J. C. The power of Influence. Benin: Joint Herirs, 2001.

[7]. The Holy Bible (King James Version)

[8]. Ozumba, G. O. in I. I. Asouzu (ed) Philosophy and Logic Today. Calabar: University of Calabar press, 2004.

[9]. Millar, C. Questions that matter: An invitation to philosophy. New York: MCgraw-Hill, 1996.

[10]. Dupre, Ben. 50 Philosophy ideas you really need to know, London: Quercus, no year. 